\title{
MONITORING DRUG THERAPY IN X's PHARMACY IN BADUNG REGENCY
}

\author{
Luh Pratiwi Diva Yanti ${ }^{1 *}$, I Made Agus Gelgel Wirasuta ${ }^{1}$, Luh Rai Maduretno Asvinigita $^{2}$ \\ ${ }^{1}$ Department of Pharmacy, Faculty of Math and Science, Udayana University \\ ${ }^{2}$ Faculty of Pharmacy, Universitas Gadjah Mada
}

Corresponding author email: pratiwidivayanti99@gmail.com

\begin{abstract}
Background: Monitoring drug therapy based on Permenkes RI No. 73 of 2016 is one of the pharmaceutical care standards in pharmacy practice. Monitoring drug therapy is a process that includes activities to ensure safe, effective and rational drug therapy for patients. Patients who receive drug therapy are at risk of experiencing drug-related problems. Objective: This study aims to determine the implementation of monitoring drug therapy in one pharmacy in Badung Regency. Methods: The type of research is a descriptive observational study conducted by interview session one pharmacist in X Pharmacy, then analyzed descriptively according to Permenkes RI No 73 of 2016. Results: The results showed that in January-June 2020 there were 34 patients with disease categories requiring monitoring drug therapy: 27 patients with asthma (79\%), six patients with diabetes (18\%), and one patient with tuberculosis (3\%). Patients with the largest visits were geriatric, which were 19 out of 34 patients. Conclusion: The monitoring of drug therapy at Pharmacy X has fulfilled all the parameters in the Standard Operating Procedure (SOP) for the implementation of in Pharmacy based on Permenkes RI No.73 of 2016.
\end{abstract}

Keywords: Monitoring drug therapy, Implementation, Pharmacy, Pharmacist

\section{INTRODUCTION}

Every pharmacist profession is obliged to practice pharmacy according to the legal requirements that apply and comply with professional and ethical standards. Based on the science of forensic pharmacy, pharmacists are involved in professional work related to litigation, regulatory processes, or the criminal justice system ${ }^{[2]}$ In government legislation number 51 of $2009^{[9]}$, explained that in practising pharmacy care facilities, pharmacists must apply the pharmaceutical care standards of pharmacy. The referred service facilities can be in the form of a pharmacy, health center, or hospital that has been arranged in each Permenkes. The current pharmaceutical service orientation has shifted from drug oriented to patient- oriented. Services that initially only focused on drug management must shift to a comprehensive service, both drug management and service to the community. It aims to improve the quality of people life.

Several studies related to the evaluation of pharmaceutical care standards in pharmacies based on legislation have been carried out ${ }^{[1,6,11]}$. Based on existing research mentioned that there are few pharmacists who do not apply it in maximum, so that needs to be reviewed more specific. One of the pharmaceutical service standards in pharmacies is monitoring drug therapy. Monitoring drug therapy is a process that includes activities to ensure safe, effective and rational drug therapy for 
patients. In legislation in force in Indonesian is regulated in Permenkes RI No. 73 of 2016 concerning Pharmaceutical Services Standards in Pharmacies ${ }^{[8]}$. Monitoring drug therapy as standard pharmacy service aimed at preventing the occurrence of unwanted events to improve the quality of pharmaceutical care, ensure legal certainty for workers and protecting the patient's pharmacy or community of irrational drug use. It has been stipulated in the constitution of Indonesian Republic number 11 of 2017 about Patient Safety ${ }^{[13]}$, which states that patient safety aims to improve the service quality of health care facilities through the implementation of risk management in all aspects of the services provided by the health care facility.

Implementation in pharmacies is based on Standard Operating Procedures (SOP) to improve the quality of pharmaceutical services provided to patients. Management has been standardized in its implementation at the Pharmacy. Those are selecting patients, collecting patient data, identifying problems, recommending therapy, monitoring, following up and documenting ${ }^{[3]}$.

\section{METHODS}

\section{Materials and Equipment}

Materials that were used in this research were the results of the interview that given to a pharmacist in X's pharmacy as the primary data and medical records in January-June 2020. The tools were a sheet of guidelines for Monitoring drug therapy and the sheet list of interview questions.

\section{Study Design}

The method of this research was observational research to conduct a survey such as interviews with a pharmacist in X's pharmacy and analysis descriptive based on Permenkes RI 73 of
2016. The identity is hidden with consideration of research ethics and has been carried out with the consent of the related person or company.

\section{RESULTS}

Based on interview results and medical record analysis, the data obtained is in the form of a diagram in figure 1 . There were 34 patients with a disease requiring monitoring drug therapy such as asthma, diabetes, and TBC.

\section{DISCUSSION}

Implementation of Monitoring Drug Therapy in X's Pharmacy in Badung Regency

$X$ 's Pharmacy is one of the pharmacies located in Badung Regency with 6 workers that consist of 2 pharmacists and 4 technical personnel pharmacy, which is in charge of doing the pharmaceutical service. In addition, there is also one other health workers that is a doctor for serving complaints of patients and provide the right diagnosis. Through the results of the interviews with one of the pharmacists that work in there, implementation of in that place is welldoing. X's Pharmacy has been doing in periodic and depends on the conditions. Conditions which meant that when the patient comes back to the pharmacy to control.

The stages of X's Pharmacy have been arranged as in table 2. Monitoring drug therapy in X's Pharmacy is carried out in stages according to Figure 1 consist of categories of patients with monitoring drug therapy at x's pharmacy JanuaryJune 2020. Several stages of monitoring drug therapy such as patient selection, recommendations therapy to patients, and assessment the success of therapy are carried out by pharmacists and doctors as health workers. The combination of these two workers health will maximize the result of for the patient. 
Table 1. Characteristics Patients with Disease Requiring Monitoring Drug Therapy in X's Pharmacy January-June 2020

\begin{tabular}{ccccccccccc}
\hline & \multicolumn{1}{c}{ Sex } & \multicolumn{10}{c}{ Age } & \\
\cline { 2 - 9 } Patient's Category & Male & Female & $<\mathbf{1 0}$ & $\mathbf{1 0}-$ & $\mathbf{2 0}-$ & $\mathbf{3 0}-$ & $\mathbf{4 0}-$ & $\mathbf{5 0}-$ & $>\mathbf{6 0}$ & Total \\
Asthma & 15 & 12 & 3 & - & - & 2 & 2 & 6 & 14 & 27 \\
\hline Diabetes & 2 & 4 & - & - & - & - & - & 2 & 4 & 6 \\
\hline TBC & 1 & - & - & - & - & - & - & - & 1 & 1 \\
\hline $\begin{array}{c}\text { Cardiovascular disease } \\
\text { (CVD) }\end{array}$ & - & - & - & - & - & - & - & - & - & - \\
\hline Hyperuricemia & - & - & - & - & - & - & - & - & - & - \\
\hline
\end{tabular}

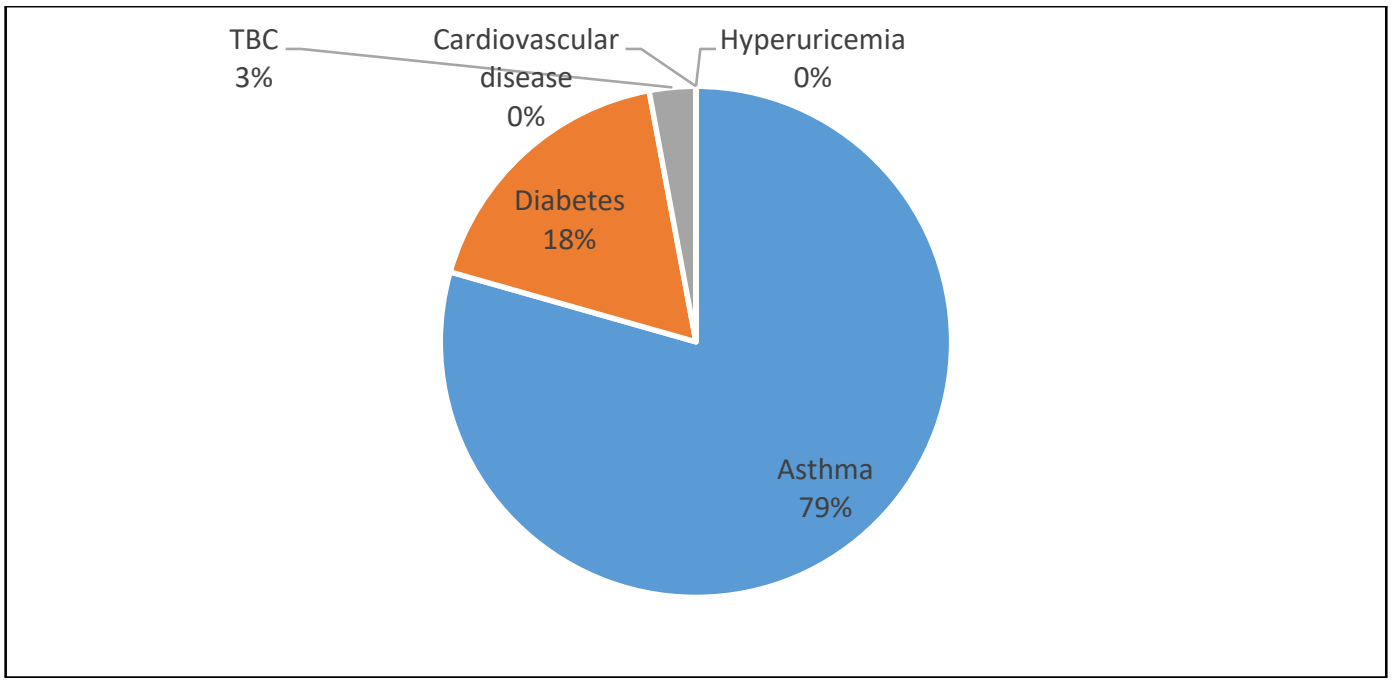

Figure 1. Categories of Patients with Disease Requiring Monitoring Drug Therapy in $X$ 's Pharmacy in January-June 2020

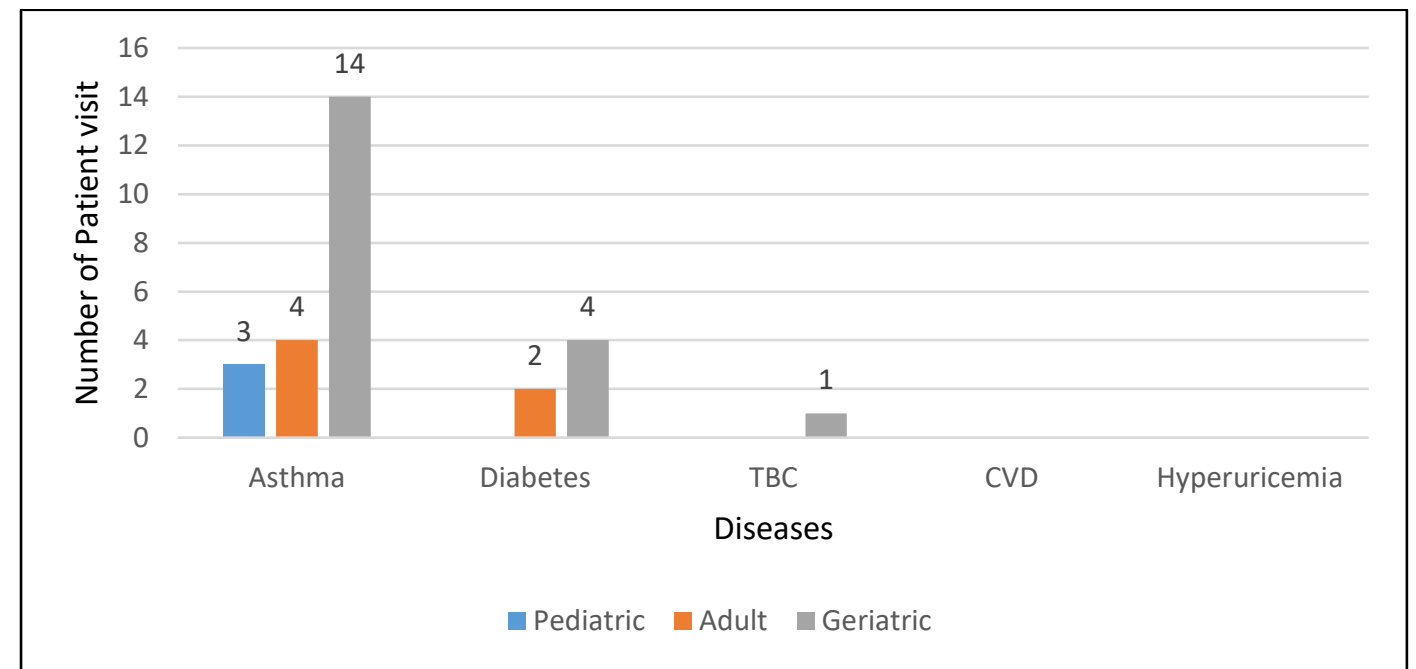

Figure 2. Patient Visit with Disease Requiring Monitoring Drug Therapy in X's Pharmacy January-June 2020

Related problems about the treatment of patients in discussions with doctors directly, such as drug dosage problem, the selection of drugs, as well as pharmacoeconomics drugs. In the Decree of the National Congress XVIII/ 2009 
Association of Indonesian Pharmacy Scholar Number: 006/ CONGRESS XVIII/ ISFI/2009 Regarding the Indonesian Pharmacist Code of Ethics ${ }^{[5]}$, it is stated that Pharmacists must treat their colleague as themselves wish to be treated. Under the terms of the then coordination with personnel health other as doctor besides aiming to implement the etic code as Pharmacists are also able to maximize the recommendation therapy with the patient medical record that given by a doctor.

Stages of patient selection in Pharmacy $\mathrm{X}$ are adjusted to the conditions as listed in table 2 and the use of drugs. Based on KepMenKes No. 1024 of 2004 concerning Pharmaceutical Service Standards in Therapeutic Drug Monitoring is carried out after patients get their drugs, especially patients with certain cardiovascular conditions, diabetes, tuberculosis, asthma, and other chronic diseases $^{[7]}$. Some of the patients who came to X's Pharmacy with this category were patients who monitored drug therapy with repeated prescriptions. The characteristics of patients visiting Pharmacy $\mathrm{X}$ in January-June 2020 are depicted in a bar diagram, as shown in Figure 2. Patient with the largest number of visits is geriatrics. Problem identification can arranged based systematic method in Guidelines for Monitoring Drugs in 2009, namely SOAP method ${ }^{[3]}$.

S: Subjective

Subjective data are symptoms that are complained of by patients. Example: dizziness, nausea, pain, shortness of breath.

O: Objective

Objective data is signed/ symptoms were measured by the health worker. Signs of objective includes pins vital (pressure of blood, the temperature of the body, throbbing pulse, speed respiration), the results of the examination laboratory and diagnostic.

\section{A: Assessment}

Based on the subjectively and objectively data carried out the identification of related drugs.

P: Plan

Do the preparation of a plan of monitoring such as that contained in the SOP as the last step in this method.

Therapeutic recommendations that given to patients are the result of discussions from pharmacists and doctors in X's Pharmacy where the role of the pharmacist is to prevent the occurrence of DRPs by ensuring side effects and adverse interactions of drugs prescribed to patients so that the therapy given is appropriate. Based on Permenkes No.73 in 2016, the pharmacist is responsible for conducting the prescription review provided by the doctor, which includes administration studies, pharmaceutical suitability, and clinical considerations such as drug interactions.

Monitoring the success of therapy to patients is done verbally when patients come to Pharmacy $\mathrm{X}$ and by utilizing social media such as Whatsapp conducted by pharmacists and doctors for evaluation. Data related to patients, therapeutic recommendations, and therapeutic success were recorded as a form of documentation. Systematic documentation is in the renewal stage to adjust to the existing condition.

\section{Implementation of Monitoring Drug Therapy based on Standard Operating Procedures (SOP)}

Implementation of proper and right will be one of the factors that were deciding to increase the quality of pharmaceutical service in pharmacy. Monitoring drug therapy in Pharmacy is regulated in the Permenkes RI No. 73 of 2016 concerning Pharmaceutical Service Standards at Pharmacy ${ }^{[8]}$. This research is carried out to see how good the implementation of the in $X$ 's Pharmacy according to regulatory legislation. 
Table 2. Stages of Monitoring Drug Therapy in X's Pharmacy

\begin{tabular}{lcc}
\hline \multicolumn{1}{c}{ Stages of Monitoring drug therapy ( in X's Pharmacy } & Who do & $\begin{array}{c}\text { Other } \\
\text { health } \\
\text { workers } \\
\text { (doctor) }\end{array}$ \\
\cline { 2 - 3 } $\begin{array}{l}\text { Do the patient selection of based on the condition of the patient } \\
\text { (for example in patients with diabetes, cholesterol, }\end{array}$ & $\begin{array}{c}\text { Pharmacy } \\
\text { technician }\end{array}$ & $\checkmark$ \\
$\begin{array}{l}\text { hyperuricemia and that require the attention of specialized, } \\
\text { geriatric, pediatric, and patients who use antibiotics and } \\
\text { psychotropic }\end{array}$ & $\checkmark$ & $\checkmark$ \\
\hline $\begin{array}{l}\text { Collecting the data of patients through the medical records, } \\
\text { interviews short when giving medicine or via WhatsApp with } \\
\text { patients and families of patients, a history of treatment as well }\end{array}$ & $\checkmark$ & $\checkmark$ \\
\hline Identification the patient problems & $\checkmark$ & $\checkmark$ \\
\hline $\begin{array}{l}\text { Make a priority scale of all patients which one is emergency } \\
\text { according to their conditions }\end{array}$ & $\checkmark$ & $\checkmark$ \\
\hline $\begin{array}{l}\text { Give recommendations therapy based on pharmacoeconomic } \\
\text { and the efficiency of treatment }\end{array}$ & $\checkmark$ \\
\hline $\begin{array}{l}\text { Discuss with doctors about conditions related to their patients } \\
\text { to get accurate data }\end{array}$ & $\checkmark$ \\
\hline $\begin{array}{l}\text { Do therapy monitoring on a patient by WhatsApp or when the } \\
\text { patient returns to X's pharmacy }\end{array}$ & $\checkmark$ \\
\hline $\begin{array}{l}\text { Evaluate the process (success or failure) } \\
\text { Recording }\end{array}$ & $\checkmark$ \\
\hline
\end{tabular}

The stages of PTO in X's Pharmacy are adjusted based on laws and regulations which have been outlined in Table 1 . The Standard Operating Procedure (SOP) of the implementation of in Indonesian Pharmacy based on Permenkes RI No.73 of 2016 is implemented as follows.

1. Patients selection by criteria

Patients selection is the stage of beginning that is required to determine patients who require priority in monitoring. Patient selection can be based on the patient's condition or the drug the patient's consuming ${ }^{[3]}$.

2. Taking the data that is needed is a history of the treatment of patients which consists of a history of the disease, a history of use of Drugs and history of allergies

Retrieval of data of patients can be through medical records. The medical record is a draft of patient data, including history, current problems statement, diagnosis and treatment procedures ${ }^{[10]}$. Data that not yet included in the medical records can be obtained by other ways such as interviews with patients or their family or force the health of others. These data are summarized and reviewed to be identified.

3. Doing the identification of problems related to medicine.

Drug-related problems are events or circumstances that involve drug treatment that really or has the potential to interfere with the optimal results of medical care in patients $^{[4]}$. Here are eight categories of problems related to drugs ${ }^{[12]}$.

a. The patient has a medical condition that requires drug therapy, but the patient is not receiving a drug for that indication.

b. There is a medical condition with the wrong drug.

c. There is a medical condition for which too little of the correct drug is being taken.

d. The patient has a medical condition for which too much of the correct drug is being taken.

e. The patient has a medical condition resulting from an adverse drug reaction. 
f. There is a medical condition like drug interaction.

g. There is a medical condition because of not receiving the prescribed drug.

h. There is a medical condition because of taking a drug for which there is no valid medical indication.

4. Pharmacist determines the priority of the problem

Based on the problem issues that have been identified, patients who require settlement soon need to be a priority.

5. Providing therapeutic recommendations

Therapeutic recommendations or plan to follow up includes a plan of monitoring with the purpose of ensuring the achievement of the effects of therapy and minimize the effects which are not desirable on therapy were given based on efficacy, safety, cost, and the regimen that acceptable for a patient ${ }^{[3]}$.

6. The results of the identification of problems related to medicine and the recommendation that has been made by pharmacists must be communicated to other workers health optimize the purpose of therapy.

7. Make documentation about the implementation of monitoring of therapeutic drugs

Documentation in aims as authentic evidence of pharmaceutical service implementation that can be used for accountability, service evaluation, education and research.

Based on the results of observations in X's Pharmacy in the Badung Regency, according to the seven points of SOP in Permenkes RI 73 of 2016, has been fulfilled all the parameters are accordance with the requirements for monitoring drug therapy based on regulations.

\section{CONCLUSION}

The implementation of pharmaceutical services in X's Pharmacy in Badung Regency showed that in January-June 2020 there were 34 patients with disease categories requiring monitoring drug therapy: 27 patients with asthma (79\%), 6 patients with diabetes $(18 \%)$, and 1 patient with tuberculosis (3\%). Patients with the largest visits were geriatric, which were 19 out of 34 patients. The monitoring of drug therapy at Pharmacy $X$ has fulfilled all the parameters in the Standard Operating Procedure (SOP) for the implementation of in Pharmacy based on Permenkes RI No.73 of 2016.

\section{CONFLICT OF INTEREST}

This paper was written without revealing the identity of the interviewees and no personal relationship between authors and related organization that can influence the results of the study.

\section{ACKNOWLEDGEMENT}

On this occasion, the author would like to thank to the X's Pharmacy in Badung Regency for the opportunity that was given to complete this research.

\section{REFERENCES}

1. Amalia, T. Evaluasi Standar Pelayanan Kefarmasian Apotek Di Apotek X berdasarkan Permenkes Nomor 73 Tahun 2016. Jurnal INKOFAR. 2019; 1(1).

2. Anderson, P. D.. The broad field of forensic pharmacy. Journal of pharmacy practice. 2019; 25(1): 7-12.

3. Depkes RI. Pedoman Pemantauan Terapi Obat. Jakarta: Departemen Kesehatan Republik Indonesia; 2009.

4. Hepler, C. D., Strand, L. M. Opportunities And Responsibilities In Pharmaceutical Care. American journal of hospital pharmacy. 1990; 47(3): 533-543.

5. ISFI. Keputusan Kongres Nasional XVIII/2009 Ikatan Sarjana Farmasi Indonesia Nomor: 006/KONGRES XVIII/ ISFI/ 2009 Tentang Kode Etik Apoteker Indonesia. Jakarta: ISFI; 2009. 
6. Istiqomah, F. N. Satibi. Evaluasi Implementasi Standar Pelayanan Kefarmasian Oleh Apoteker. Jurnal Manajemen dan Pelayanan Farmasi, 2012; 2(3): 127-132.

7. Kepmenkes RI. Keputusan Menteri Kesehatan Republik Indonesia N0.1024 Tahun 2004. Jakarta: Menteri Kesehatan Republik Indonesia; 2004.

8. Permenkes RI. Peraturan Menteri Kesehatan Republik Indonesia No.73 Tahun 2016. Jakarta: Menteri Kesehatan Republik Indonesia; 2016.

9. Peraturan Pemerintah No.51 tahun 2009 tentang Pekerjaan Kefarmasian.

10. Raza, M. Good Medical Record Keeping. International Journal of Collaborative Research on Internal Medicine \& Public Health. 2012; 4(5).

11. Saputra, Y. D., Choirunnisa, N. F., Arisca, Z. Z. Evaluasi Implemantasi Standar Pelayanan Kefarmasian Di Apotek Perorangan Dan Waralaba Wilayah Kota Yogyakarta Tahun 2019. Jurnal Kefarmasian Akfarindo. 2019: 11-20.

12. Strand, L. M., Morley, P. C., Cipolle, R. J., Ramsey, R., Lamsam, G. D. Drug-Related Problems: Their Structure And Function. Dicp. 1990; 24(11): 1093-1097.

13. Undang-Undang Republik Indonesia Nomor 11 tahun 2017 tentang Keselamatan Pasien. 